\title{
Brodie Abscess in a Previously Healthy Boy
}

\section{Öncesinde Sağlıklı Erkek Hastada Brodie Absesi}

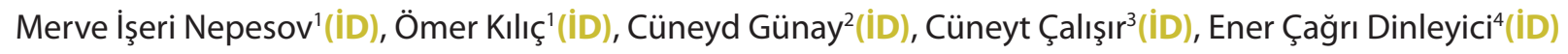 \\ ${ }^{1}$ Department of Pediatrics, Division on Pediatric Infectious Diseases, Osmangazi University Faculty of Medicine Hospital, Eskişehir, Turkey \\ 2 Department of Orthopedics and Traumatology, Osmangazi University Faculty of Medicine Hospital, Eskişehir, Turkey \\ ${ }^{3}$ Department of Radiology, Osmangazi University Faculty of Medicine Hospital, Eskişehir, Turkey \\ ${ }^{4}$ Department of Pediatrics, Osmangazi University Faculty of Medicine Hospital, Eskişehir, Turkey
}

Cite this article as: Iş̧eri Nepesov M, Kılıç Ö, Günay C, Çalışır C, Dinleyici EÇ. Brodie abscess in a previously healthy boy. J Pediatr Inf 2021;15(3):e188-e191.

\section{Introduction}

Brodie abscess is a subacute form of hematogenous osteomyelitis, and it is characterized by an infectious process in the bony tissue persisting for longer than 2 weeks without any systemic symptoms. It was first described in 1832 by Sir Benjamin Brodie $(1,2)$. It is a rare form of osteomyelitis and accounts for only $2 \%$ of all osteomyelitis cases (3). When compared with acute osteomyelitis, it shows insidious progress (4). Its diagnosis is primarily based solely on radiological features. The main treatment modality is curettage of the abscess cavity, cancellous bone grafting, and antibiotic therapy $(2,3)$.

\section{Öz}

Brodie apsesi, nadir görülen bir osteomiyelit formudur. Atipik klinik özelliklerinden dolayı tanı genellikle gecikir. Burada, daha öncesinde sağlıklı olup herhangi bir risk faktörü olmayan erkek çocukta sağ distal tibiada lokalize olan Brodie apsesi sunulmaktadır. Tanı manyetik rezonans görüntüleme ve kemik biyopsisi ile konuldu. Hasta antibiyotik tedavisi ve apsenin cerrahi olarak boşaltılması ile başarıyla tedavi edildi.

Anahtar Kelimeler: Brodie apsesi, çocuk, osteomiyelit

\section{Case Report}

A 17-year-old boy was presented with progressive right leg pain and swelling for 1 month. He had no history of constitutional symptoms, such as fever, weight loss, or recent trauma. He had three outpatient clinical visits and received only nonsteroidal anti-inflammatory drugs. He displayed no improvement in symptoms after treatment with nonsteroidal anti-inflammatory drugs. The patient had no history of chronic diseases, such as immunodeficiency disorder, hospitalization, or regular drug use. Physical examination revealed swelling and local redness in the anterolateral part of his right 
ankle. He also had hyperpigmented skin lesions around the ankle and limited active and passive range of movement in his right ankle. Other physical examination findings were normal. Laboratory examinations were conducted, and the results were the following: white blood cell count, $9.200 / \mathrm{mm}^{3}$ ( $70 \%$ neutrophil); hemoglobin count, $14.2 \mathrm{~g} / \mathrm{dL}$; and platelet count, $272.000 / \mathrm{mm}^{3}$. The erythrocyte sedimentation rate was $53 \mathrm{~mm} / \mathrm{h}$, and C-reactive protein was $4.69 \mathrm{mg} / \mathrm{dL}(<0.5 \mathrm{mg} /$ $\mathrm{dL}$ ). Plain radiographs of the right distal cruris demonstrated a lucent ovoid lesion with a sclerotic margin centered at the tibial metaphysis (Figure 1). The lesion was hyperintense on fat-saturated proton density (PD)-weighted images. Pre- and post-contrast magnetic resonance imaging (MRI) revealed a regular hypointense intramedullary lesion that was $4 \mathrm{~cm}$ in diameter in the distal metaphysis of the tibia on non-contrast, enhanced T1-weighted images with a surrounding rim of high signal intensity (Figure 2). Extensive bone marrow edema, cortical thickening, periosteal reaction, and deep soft tissue edema were also evident. He was diagnosed with Brodie abscess. For treatment, intravenous teicoplanin and imipenem were

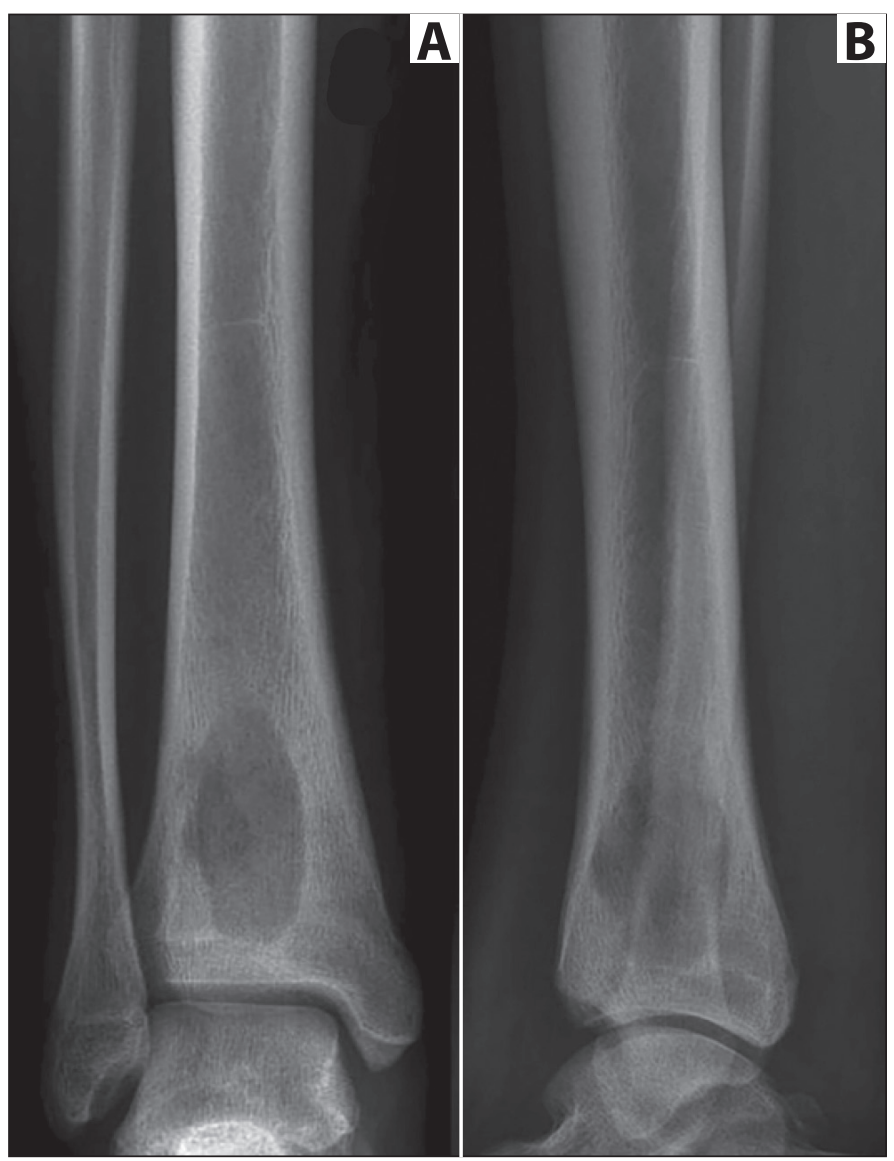

Figure 1. Anteroposterior (A) and lateral (B) radiographs of the right distal cruris: A well-defined radiolucent lesion in the distal metaphysis of the tibia is noted. The lesion does not show the usual well-defined marginal sclerosis. Note also the periosteal thickening along the posterior surface of the tibia. started. Bone biopsy was performed, and results revealed chronic inflammation with no malignant cells. No pathogenic microorganism growth was observed in cultures. The patient underwent arthrotomy of the right ankle with a surgical procedure for excision. Furthermore, debridement of the abscess cavity and placement of antibiotic-impregnated beads after a preoperative course of antibiotic therapy were also performed. Patient received intravenous teicoplanin and imipenem for 14 days. After discharge, oral clindamycin was taken for 14 days. The patient returned to school 1 month after being discharged from the hospital. The outcome was favorable after a 2-year follow-up.

\section{Discussion}

In developed countries, osteomyelitis rates are 2 to 13 per 100.000 children. In developing countries, the frequency is believed to be higher since it can lead to long term complications, such as fractures, limb deformities, and deep venous thrombosis, it remains a crucial infectious disease (5). Brodie abscess is a form of subacute osteomyelitis, and it is defined as a confined abscess surrounded by a sclerotic rim of dense bone, typically seen in the metaphases of long bones. Patients are mainly young adult males who have local symptoms and nearly normal laboratory results (5-7). Pain, swelling, and local tenderness are the most common symptoms $(2,3)$. A recent review has suggested that whereas fever was not observed in the majority of patients, leukocyte count, erythrocyte sedimentation rate, and C-reactive protein values fell within the normal range in more than half of patients (8). As seen in our patient, slowly progressive and non-severe clinical findings and a lack of significant elevation in acute phase reactants make diagnosis difficult.

In studies, the tibia and femur are the most frequently involved bones; however, Brodie abscess formation has been described in almost every bone in the literature (8). Because of atypical presentation, the diagnosis is usually delayed, and the average duration of symptoms before presentation is nearly 2 months; however, some authors have reported that the average length of symptoms was more than 5 months $(2,3)$. The patient history of our case included three outpatient clinic visits; however, he received only analgesic. Brodie abscess should be considered if symptoms persist in the same extremity even if there are no underlying risk factors.

Although Staphylococcus aureus is the most frequently isolated agent, the pathogen cannot be detected in a significant proportion of patients (5-7). In our patient, no pathogen was detected although both aerobic and anaerobic cultures were studied and specimens were taken intraoperatively. The case was accepted as culture-negative osteomyelitis. 

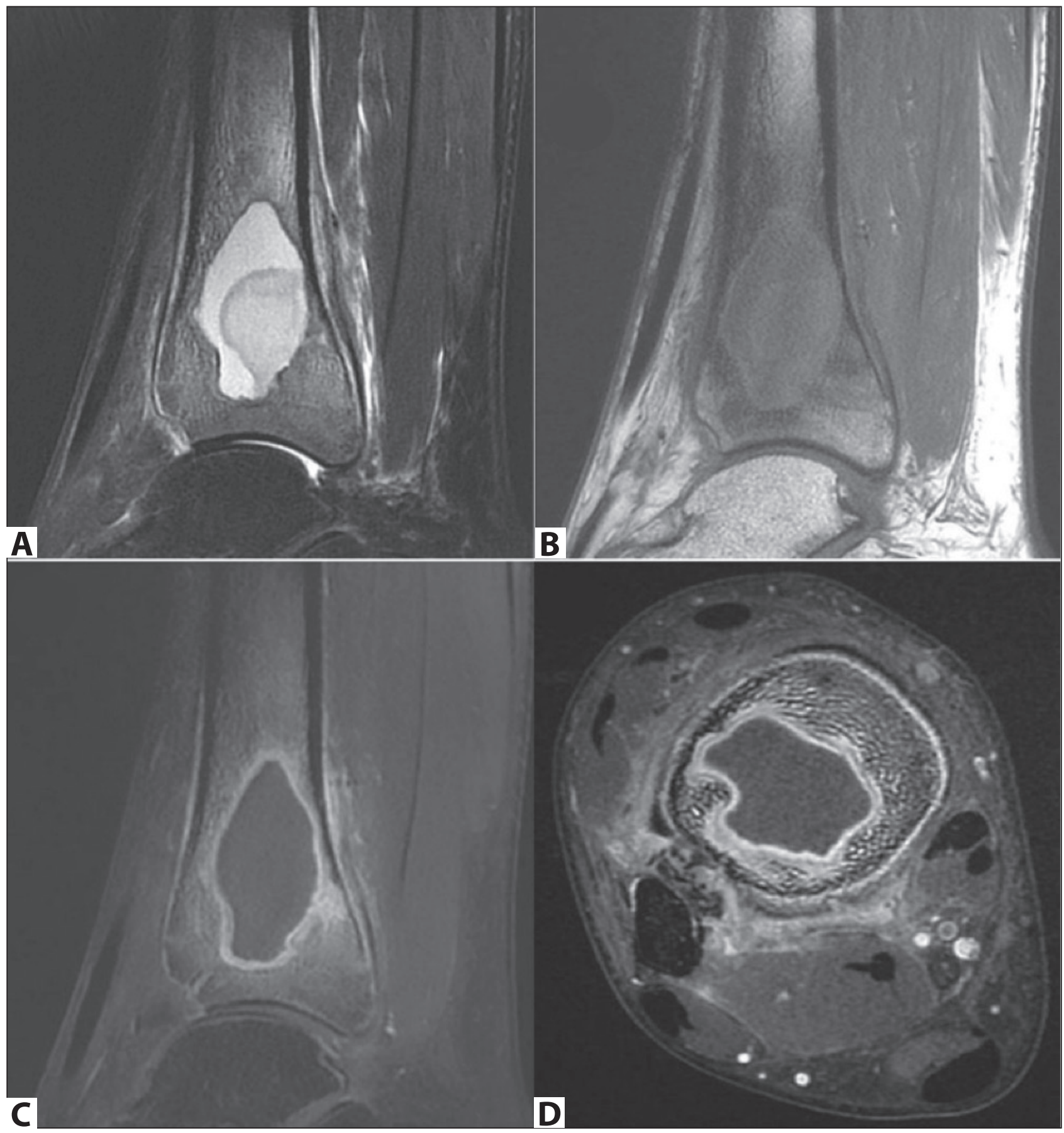

Figure 2. Sagittal fat-saturated proton density (PD)-weighted (A) and sagittal T1 weighted (B) MR images demonstrate a well-defined intramedullary lesion in the distal metaphysis of the tibia with a surrounding rim, which appears with hypointense on T1 and hyperintense on PD. The lesion appears with low signal intensity on $\mathrm{T} 1$ and high signal intensity on PD relative to the yellow marrow. Also identified is a surrounding extensive signal-intense abnormality representing marrow edema. After gadolinium contrast administration sagittal (C) and axial (D) T1 weighted fat saturated images, the central part of the lesion was non-enhanced; however, subtle peripheral rim enhancement with moderate enhancement of the surrounding bone marrow and soft tissue edema were observed. There were also cortical thickening and periosteal reaction surrounding the bone.

Several imaging modalities, such as conventional radiography, sonography, scintigraphy, computed tomography-scan, or MRI are used in osteomyelitis diagnosis. Whereas conventional $\mathrm{x}$-ray is usually the first step, MRI is the recom- mended modality in differential diagnosis (4). Radiographically, the Brodie abscess can have a variable appearance, but the "Target Sign" on MRI has been characteristic for the Brodie abscess. This target image is produced by four layers of tissue. 
The center of the lesion is composed of necrotic tissue that is surrounded by granulation tissue. The next layer is composed of sclerotic tissue surrounded by edema (9). A Brodie abscess lesion may mimic many other infectious processes or neoplasms, such as osteoid osteoma, chondroblastoma, giant cell tumor, Langerhans cell histiocytosis, or Ewing's sarcoma $(8,9)$. For our patient, radiography and MRI findings suggested Brodie abscess so antibiotic therapy was started; however, before the operation, a biopsy was performed for definitive diagnosis. Histopathology showed chronic non-specific inflammatory cell infiltration and new bone formation with no evidence of malignancy.

Treatment of Brodie abscess remains controversial. Therefore, treatment depends on clinician preference and experience (8). Surgical and intravenous antibiotic therapy are the two main treatment modalities, and rarely are there cases of patients who have undergone antibiotic treatment or surgery alone. The duration of treatment varies among centers from 10 days to 3 months (8).

In conclusion, Brodie abscess diagnosis is clinically difficult because patients generally display mild local symptoms that are not systemic and nearly normal laboratory results. Radiological evaluation plays an important role in diagnosis; however, Brodie abscess may mimic various benign or malignant conditions. Since no consensus about treatment and diagnosis currently exists, each case will contribute to developing a proper approach to the disease.

Informed Consent: Patient consent was obtained.

Peer-review: Externally peer-reviewed.

Author Contributions: Concept - MiN, ÖK; Design - MiN, ÖK; Supervision - ÖK, CG, CÇ, EÇD; Resources - MiN, CÇ; Data Collection and/or Processing - MiN, ÖK, CG, CÇ, EÇD; Analysis and/or Interpretation - ÖK, CG, CÇ, EÇD; Literature Review - MiN, ÖK; Writing - MiN, ÖK; Critical Review - ÖK, CG, CÇ, EÇD.
Conflict of Interest: No conflict of interest was declared by the authors.

Financial Disclosure: The authors declared that this study has received no financial support.

\section{References}

1. Brodie BC. An account of some cases of chronic abscess of the tibia. Med Chir Trans 1832;17:239-49. [CrossRef]

2. Shih HN, Shih $L Y$, Wong YC. Diagnosis and treatment of subacute osteomyelitis. J Trauma 2005;58:83-7. [CrossRef]

3. Olasinde AA, Oluwadiya KS, Adegbehingbe OO. Treatment of Brodie's abscess: excellent results from curettage, bone grafting and antibiotics. Singapore Med J 2011;52:436-9. [CrossRef]

4. Jaramillo D, Dormans JP, Delgado J, Laor T, St Geme JW. Hematogenous osteomyelitis in infants and children: imaging of a changing disease. Radiology 2017;283:629-43. [CrossRef]

5. Dodwell ER. Osteomyelitis and septic arthritis in children: current concepts. Curr Opin Pediatr 2013;25:58-63. [CrossRef]

6. Johnson JW, Bindra RR. Brodie's abscess of the distal radius: an unusual complication after percutaneous pinning. Hand (NY) 2008;3:381-4. [CrossRef]

7. Kanoun ML, Khorbi A, Khmiri C, Tebourbi A, Hadded N, Boughzala W, et al. Diagnosis and treatment of Brodie's abcess in adults: about twenty cases. Tunis Med 2007;85:857-61. [CrossRef]

8. van der Naald N, Smeeing DPJ, Houwert RM, Hietbrink F, Govaert GA, van dee Velde $D$. Brodie's abscess: a systematic review of reported cases. J Bone Jt Infect 2019;4:33-9. [CrossRef]

9. Gould CF, Ly JQ, Lattin GE Jr, Beall DP, Sutcliffe JB $3^{\text {rd }}$. Bone tumor mimics: avoiding misdiagnosis. Curr Probl Diagn Radiol 2007;36:12441. [CrossRef] 